ISSN : 2580-3220, E-ISSN : 2580-4588

J. Mandiri., Vol. 2, No. 1, Juni 2018 (139 - 158)

(C)2018 Lembaga Kajian Demokrasi

dan Pemberdayaan Masyarakat (LKD-PM)

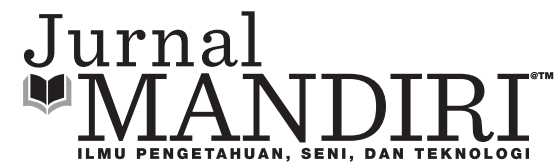

\title{
PENGARUH TATA KELOLAH PEMILIH DAN LOGISTIK PEMILU TERHADAP EPEKTIFITAS PEMILU GUBERNUR DAN WAKIL GUBERNUR BANTEN TAHUN 2017 DI KPU KOTA TANGERANG
}

\author{
Ahmad Nazir \\ Fakultas Ekonomi, Universitas Pamulang \\ naziramangkurat@gmail.com
}

\begin{abstract}
Abstrak
Terdapat pengaruh positif dan signifikan antara Tata Kelolah Pemilih $\left(X_{1}\right.$ Terhadap Efektivitas Pemilu Gubernur dan Wakil Gubernur Banten Tahun 2017(Y) sebesar 0.315. Koefesien korelasi ini signifikan dan memiliki tingkat hubungan rendah berada pada interval nilai 0.200-0.399. Terdapat pengaruh positif dan signifikan Penyiapan Logistik Pemilu (X2) Terhadap Efektivitas Pemilu (Y) sebesar 1.000. Koefesien korelasi ini signifikan dan memiliki tingkat hubungan sangat tinggi berada pada interval nilai 0.800-1.000. Sedangkan hasil uji statistic korelasi berganda (R) menujukan terdapat pengaruh positif dan signifikan antara Tata Kelolah Pemilih (X1) dan Penyiapan Logistik Pemilu (X2) Terhadap Efektivitas Pemilu Gubernur dan Wakil Gubernur Banten Tahun 2017(Y) sebesar 0.329. Hal ini menujukan adanya pengaruh lemah antara Tata Kelolah Pemilih (X1) dan Penyiapan Logistik Pemilu (X2) secara bersamasama terhadap efektivitas Pemilu Gubernur dan Wakil Gubernur Banten Tahun 2017 (Y). Hasil uji thitung yang dikonsultasikan t tabel hasilnya ternyata variable Tata Kelolah Pemilih terhadap variable Efektivitas Pemilu hasil uji hipotesis ke-1 Ho ditolak dan Ha diterima karena $t_{\text {hitung }}(3.114)>t_{\text {tabel }}(1.980)$. Variabel Penyiapan Logistik Pemilu terhadap Variabel Y hasil uji hipotesis ke-2 Ha diterima dan Ho ditolak karena $t_{\text {hitung }}(2.157)>t_{\text {tabel }}$ (1.980). Selanjutnya untuk variable X1 (Tata Kelolah Pemilih) dan Variabel X2 (Penyiapan Logistik Pemilu) terhadap variable Y uji hipotesis ke-3 Ha diterima dan Ho ditolak setelah dikonsultasikan dengan $F$ tabel ternyata $F_{\text {hitung }}(5.272)>F_{\text {tabel }}$ (1.39), maka secara bersama-sama Tata Kelola Pemilih dan Penyiapan Logistik Pemilu berpengaruh terhadap Efektivitas Pemilu Gubernur dan Wakil Gubernur Banten Tahun 2017.
\end{abstract}

Kata Kunci $\quad$ :Tata Kelola, Penyiapan Logistik, Efektivitas Pemilu

\section{PENDAHULUAN}

\section{Latar Belakang}

Pemilihan umum pada hakekatnya merupakan pengakuan dan perwujudan daripada hak-hak politik rakyat dan sekaligus me- rupakan pendelegasian hak-hak tersebut oleh rakyat kepada wakil-wakilnya untuk menjalankan pemerintahan. Formulasi lain menyatakan bahwa pemilu merupakan sarana pelaksana asas kedaulatan rakyat berdasarkan 
pancasila (Demokrasi Pancasila) dalam Negara Kesatuan Republik Indonesia. Tujuannya adalah untuk memilih wakil-wakil rakyat yang akan duduk dalam badan perwakilan rakyat, yang membawakan isi hati nurani rakyat.

Pada pasa 1 ayat (2) Undang-Undang Dasar Republik Indonesia Tahun 1945 menyatakan bahwa "kedaulatan berada di tangan rakyat dan dilaksanakan menurut Undang-Undang Dasar”. Makna dari "kedaulatan berada di tanga rakyat" adalah bahwa rakyat memiliki kedaulatan, tanggung jawab, hak dan kewajiban untuk secara demokratis memilih pemimpin yang akan membentuk pemerintahan guna mengurus dan melayani seluruh lapisan masyarakat, serta memilih wakil rakyat untuk mengawasi jalannya pemerintahan. Perwujudan kedaulatan rakyat dilaksanakan melalui pemilihan umum secara langsung sebagai sarana bagi rakyat untuk memilih wakilnya yang akan menjalankan fungsi melakukan pengawasa, penyaluran aspirasi politik rakyat, membuat Undang-undang sebagai landasan bagi semua pihak di Negara Kesatuan Republik Indonesia dalam menjalankan fungsi masing-masing, serta merumuskan anggaran pendapatan dan belanja untuk membiyayai pelaksana fungsi-fungsi tersebut.

Sesuai dengan ketentuan Pasal22E UndangUndang Dasar Negara Republik Indonesia Tahun 1945 , pemilihan umum untuk memilih anggota Dewan Perwakilan Rakyat, Dewan Perwakilan Daerah dan Dewan Perwakilan Rakyat Daerah diselenggarakan berlandaskan asas langsung, umum, bebas, rahasia, jujur dan adil setiap lima tahun sekali. Pemilihan umum diselenggarakan dengan menjamin prinsip keterwakilan, yang artinya setiap warga Negara Indonesia dijamin memiliki wakil yang duduk di lembaga perwakilan yang akan menyuarakan aspirasi rakyat di setiap tingkatan pemerintahan dari pusat hingga ke daerah. Pemilu yang dilaksanakan secara langsung, umum, bebas, rahasia, jujur, dan adil merupakan syarat untuk mewujudkan wakil rakyat yang berkualitas, dapat dipercaya, dan dapat menjalankan fungsi kelembagaan legislatif secara optimal. Penyelenggaraan pemilu yang baik dan berkualitas akan meningkatkan derajat kompetisi yang sehat, partisipatif, dan keterwakilan yang makin kuat dan dapat dipertanggungjawabkan.

Undang-Undang No. 10 Tahun 2016 Tentang perubahan kedua atas Undang-undang No 1 Tahun 2015 tentang penetapan peraturan pemerintah pengganti undang-undang no 1 tahun 2014 tentang Pemilihan Gubernur, Bupati dan Walikota menjadi undang-undang di dalamnya juga mengatur bahwa partai politik atau gabungan partai politik dapat mendaftarkan satu pasangan calon (Gubernur dan Wakil Gubernur) jika telah memenuhi perolehan suara paling sedikit 20\% dari jumlah kursi di Dewan Perwakilan Rakyat Daerah atau 25\% dari akumulasi perolehan suara sah dalam pemilihan umum anggota Dewan Perwakilan Rakyat Daerah yang bersangkutan

Undang-Undang No. 8 Tahun 2012 Bab IV mengatur Penyusuna Dafatr pemilih di dalamnya mengatur Perlindungan hak konsitisi warga Negara Indonesia yang menggunakan hak pilih dalam pemilu dan yang belum terdaftar sebagai pemilih diatur dengan jaminan hak memilih dengan menggunakan bukti kartu tanda penduduk atau paspor. Melalui undangundang ini juga dibentuk sistem informasi data pemilih yang berisi data pemilih secara nasional yang wajib dipelihara dan dimutahirkan oleh Komisi Pemilihan umum kabupaten/ Kota di bantu oleh PPK dan PPS agar dapat digunakan dalam pemilu selanjutnya. Dan Undang-Undang No. 8 Tahun 2012 pada Bab IX mengatur perlengkapan pemungutan suara atau persiapan logistik pada pemungutan suara anggota Dewan Perwakilan Rakyat, Dewan Perwakilan Daerah, dan Dewan Perwakilan Rakyat Daerah yang sering kita sebut dengan istilah legislatif.

Walaupun KPU telah menetapkan dafar pemilih tetap dari berbagai jenjang tingkatan, tetap saja masih menuai keritikan pada daftar 
pemilih tersebut karena belum terkaper secara keseluruhan masyarakat kita di dalam daftar pemilih tersebut, masih ada saja yang belum terdaftar dalam pemilih tetap dan sebaliknya yaitu orangnya sudah pindah atau meninggal masih saja terdaftar dalam daftar pemilih tetap, termasuk Pengolahan Daftar Penduduk Potensial Pemilih Pemilu (DP4) dari Dinas Kependudukan dan Catatan Sipil.

Carut-marutnya daftar pemilih menjadi sorotan yang paling serius kepada pelaksana pemilu yaitu KPU sebagai penyelenggara pemilu dari berbagai jenjang. Dari pemilu ke pemilu sekiranya yang paling mendapatkan sorotan yang sangat serius adalah terletak pada Daftar Pemilih Tetap. Walaupun sekiranya Pemilu Gubernur dan Wakil Gubernur Banten 2017 sudah menggunakan sistem daftar pemilih (sidalih) secara online, diharapkan masyarakat berpartisifasi secara aktif untuk melihat daftar pemilih tersebut, dan yang belum terdaftar agar segera mendaftarkan dirinya kepada PPS atau kelurahan setempat. Kendati demikian masih saja di waktu pelaksanaan pemungutan suara masih ribut belum menerima undangan atau panggilan untuk menggunakan hak pilih di Tempat Pemungutan Suara (TPS) dari Kelompok Penyelenggara Pemungutan Suara (KPPS).

Permasalahan logistik bukan hanya pada kotak suara, tinta sebagai tanda bukti pemilih telah memberikan suaranya juga ternyata mudah luntur. Begitu juga dengan adanya kertas suara yang rusak dan telah dicoblos nama calon tertentu. logistik pemilu yang bermasalah sangat berpotensi untuk menimbulkan terjadinya kecurangan, Kotak suara yang terbuat dari kardus bisa saja dilubangi oleh pihak yang tidak bertanggung jawab. Selain itu jika kotak suara terjatuh, apakah bisa dijamin bahwa kotak suara tersebut tetap utuh. Kotak suara yang berbahan alumunium saja masih bisa dicurangi apalagi kotak suara yang berbahan kardus. Walaupun KPU sudah mempersiapkannya dengan matang terlihat menjadi kurang maksimalnya persiapan dan pengolahan logistik dalam Pemilu Gubernur dan Wakil Gubernur Tahun 2017, apabila di sana sini masih banyak yang meributkan logistik pemilu. Terlebih jadwal yang telah ditetapkan oleh KPU tidak adanya kesesuai jadwal antara pengadaan dan pengiriman serta penerimaa logistik pemilu, baik di KPU Kabupaten/Kota, PPK dan PPS.

\section{Perumusan Masalah}

Berdasarkan latar belakang masalah di atas, maka masalah dalam penelitian ini dapat dirumuskan sebagai berikut:

1. Apakah ada pengaruh yang signifikan tata kelola data pemilih terhadap efektivitas Pemilu Gubernur dan Wakil Gubernur Banten 2017 ?

2. Apakah ada pengaruh yang signifikan persiapan logistik pemilu terhadap efektivitas Pemilu Gubernur dan Wakil Gubernur Banten 2017 ?

3. Apakah ada pengaruh yang signifikan tata kelola data pemilih dan persiapan logistik pemilu terhadap efektivitas Pemilu Gubernur dan Wakil Gubernur Banten 2017 ?

\section{Tujuan Penelitian}

Tujuan dalam penelitian ini adalah, sebagai berikut:

1. Untuk mengetahui pengaruh yang signifikan tata kelola data pemilih terhadap efektivitas Pemilu Gubernur dan Wakil Gubernur Banten 2017.

2. Untuk mengetahui pengaruh yang signifikan persiapan logistik pemilu terhadap efektivitas Pemilu Gubernur dan Wakil Gubernur Banten 2017.

3. Untuk mengetahui pengaruh tata kelola data pemilih dan persiapan logistik pemilu terhadap efektivitas Pemilu Gubernur dan Wakil Gubernur Banten 2017 


\section{Kajian Teoritik}

\section{Tata Kelolah Pemilih}

Menurut Gillan \& Starks (2006) dalam Gillan (2006:43) mendefinisikan tata kelola perusahaan sebagai sistem dari hukum-hukum, gangguan-gangguan, dan faktor-faktor yang mengontrol operasi pada perusahaan. Dengan mengabaikan definisi khusus yang biasa digunakan, penelitian-penelitian biasanya melihat mekanisme tata kelola perusahaan sebagai masuknya satu dari dua kelompok: baik internal perusahaan atau eksternal perusahaan.

Menurut Rowland.B.F. Pasaribu (2012:397) Pemerintah atau "Government" dalam bahasa Inggris diartikan sebagai "The authoritative direction and administration of the affairs of men/ women in a nation, state, city, etc" (pengarahan dan administrasi yang berwenang atas kegiatan orang-orang dalam sebuah negara, negara bagian, kota, dan sebagainya). Ditinjau dari sisi semantik, kebahasaan governance berarti tata kepemerintahan dan good governance bermakna tata kepemerintahan yang baik. Di satu sisi istilah good governance dapat dimaknai secara berlainan, sedangkan sisi yang lain dapat diartikan sebagai kinerja suatu lembaga, misalnya kinerja pemerintahan, perusahaan atau organisasi kemasyarakatan.

Nuning Akhmadi dkk, (2004:21) mendefinisikan tata kelola pemerintahan yang baik, dengan merujuk makna good governence dengan pengertian. "Suatu pelayanan publik yang efisien, sebuah sistem peradilan yang dapat dipercaya, dan sebuah sistem pemerintahan yang bertanggung jawab kepada publik.

Syarat-syarat pemilih dalam Pemilu menurut UU Republik Indonesia No.3 Tahun 1999 tentang pemilihan umum adalah sebagai berikut:

- WNI yang pada waktu pemungutan suara untuk Pemilihan Umum sudah berumur 17 (tujuh belas) tahun atau sudah/pernah kawin.

- Harus terdaftar sebagai pemilih.

- Untuk dapat didaftar sebagai pemilih harus dipenuhi syaratsyarat sebagai berikut:

a. nyata-nyata tidak sedang terganggu jiwa/ingatannya;

b. tidak sedang menjalani pidana penjara atau pidana kurungan berdasarkan putusan Pengadilan yang telah memperoleh kekuatan hukum tetap, karma tindak pidana yang diancam dengan pidana penjara 5 (lima) tahun atau lebih;

c. tidak sedang dicabut hak pilihnya berdasarkan putusan Pengadilan yang telah memperoleh kekuatan hukum tetap.

Seorang warga negara yang setelah terdaftar dalam daftar pemilih ternyata tidak lagi memenuhi syarat sebagaimana dimaksud pada poin a.b.c diatas tidak dapat menggunakan hak memilihnya.

\section{Logistik Pemilu}

Menurut Lukas dan Rumsari (2004:79) mengatakan bahwa Pengadaan Logistik merupakan serangkaian kegiatan untuk menyediakan logistik sesuai dengan kebutuhan, baik berkaitan dengan jenis, spesifikasi, jumlah, waktu maupun tempat dengan harga dan sumber yang dapat dipertanggungjawabkan.

Berdasarkan Keppres RI No. 54 tahun 2010 Pengadaan Barang/Jasa Pemerintah yang selanjutnya disebut dengan Pengadaan Barang/ Jasa adalah kegiatan untuk memperoleh Barang/Jasa oleh Kementerian/Lembaga/Satuan Kerja Perangkat Daerah/Instansi lainnya yang prosesnya dimulai dari perencanaan kebutuhan sampai diselesaikannya seluruh kegiatan untuk memperolehnya.

Berdasarkan Inpres RI No.1 Tahun 1998 Tata cara pengadaan barang dan jasa merupakan bagian yang penting dari pada usaha untuk lebih meningkatkan daya guna penga dan barang dan jasa yang dibutuhkan departemen dan berbagai intansi pemerintah, bank-bank milik pemerintah, serta badan-badan usaha milik Negara dan milik daerah. 
Secara umum Asas logistik yang berlaku secara universal meliputi:

(a) Logistik akan senantiasa mengikuti dan menyesuaikan secara terus menerus terhadap kebutuhan operasional dan perkembangan tehnologi.

(b) Logistik harus senantiasa bertumpu pada kemampuan ekonomi atau mendasarkan pada kemampuan anggaran yang disediakan oleh pemerintah.

(c) Logistik harus senantiasa patuh dan mengikuti/mempedomani ketentuan/ perundangan yang berlaku.

Berdasararkan paal 3 PKPU No. 16 Tahun 2013 Tentang Norma, Standar Kebutuhan Pengadaan dan Pendistribusian Perlengkapan Penyelenggaraan Pemilihan Umum, menyatakan bahwa: Penyediaan Perlengkapan penyelenggaraan Pemilu dilaksanakan berdasarkan prinsip-prinsip: tepat jumlah, tepat jenis, tepat sasaran, tepat waktu, tepat kualitas, dan hemat anggaran/ efesiensi.

Pasal 142 UU RI No.8 Tahun 2012 menyatakan bahwa:

(1). Perlengkapan pemungutan suara sebagaimana dimaksud dalam pasal 141 terdiri atas:
a. kotak suara
b. surat suara
c. tinta
d. bilik pemungutan suara
e. segel
f. alat untuk mencoblos pilihan
g. tempat pemungutan suara

(2). Selain perlengkapan pemungutan suara sebagaimana dimaksud pada ayat (1), untuk menjaga keamanan, kerahasiaan, dan kelancaran pelaksanaan pemungutan suara dan penghitungan suara, diperlukan dukungan perlengkapan lainnya.

Dukungan perlengkapan lainnya berdasarkan pasal 5 PKPU No. 16 Tahun 2013 terdiri atas: sampul kertas, formulir, stiker nomor kotak suara, alat bantu tuna netra, perlengkapan di TPS/ TPS LN, Daftar Calon Tetap (DCT).
The Liang Gie (2000:24) juga mengemukakan "efektivitas adalah keadaan atau kemampuan suatu kerja yang dilaksanakan oleh manusia untuk memberikan guna yang diharapkan."

Sedangkan menurut pendapat Gibson (2004:28) mengemukakan bahwa "efektivitas adalah konteks perilaku organisasi merupakan hubungan antar produksi, kualitas, efisiensi, fleksibilitas, kepuasan, sifat keunggulan dan pengembangan."

Westra (2009: 147) mengatakan efektivitas adalah suatu keadaan yang mengandung pengertian mengenai terjadinya suatu efek atau akibat yang dikehendaki. Kalau seseorang melakukan perbuatan dengan maksud tertentu yang memang dikehendaki, maka orang itudikatakan efektif kalau menimbulkan akibat sebagaimana yang dikehendaki.

Gomes (2003:52) memberi tipe-tipe kriteria efektivitas program. Suatu program biasa dievaluasi berdasarkan: (1) reactions, (2) learning, (3) behaviors, (4) organizational results.

Melalui reactions (reaksi) dapat diketahui opini dari para peserta mengenai program yang diberikan. Proses learning (belajar) memberikan informasi yang ingin diperoleh melalui penguasaan konsep-konsep, pengetahuan, dan keterampilan-keterampilan yang diberikan selama pelaksanaan. Behaviors (perilaku) dari peserta, sebelum dan sesudah pelaksanaan, dapat dibandingkan guna mengetahui tingkat pengaruh pelaksanaan terhadap peserta. Organizational results (dampak pelaksanaan) untuk menguji dampak pelaksanaan terhadap peserta secara keseluruhan.

\section{METODELOGI PENELITIAN Desain Penelitian}

Pengertian dari metode deskriptif analisis menurut Moh. Nazir (2003:71), adalah: "Penelitian yang ditujukan untuk menyelidiki secara terperinci aktivitas dan pekerjaan manusia dan hasil penelitian tersebut dapat memberikan rekomendasi-rekomendasi untuk keperluan 
masa yang akan datang.”

Sedangkan pengertian kuantitatif menurut Sugiyono (2007:13), adalah: "Metode penelitian kuantitatif dapat diartikan sebagai metode penelitian yang berlandaskan pada filsafat positivisme, digunakan untuk meneliti pada populasi atau sampel tertentu, teknik pengambilan sampel pada umumnya dilakukan secara random, pengumpulan data menggunakan instrumen penelitian, analisis data bersifat kuantitatif atau statistik dengan tujuan untuk menguji hipotesis yang telah ditetapkan.”

Berdasarkan pengertian diatas, maka penelitian yang dilakukan adalah dengan metode deskriptif kuantitatif yaitu suatu bentuk penelitian yang berdasarkan data yang dikumpulkan selama penelitian secara sistematis mengenai fakta-fakta dan sifat-sifat dari obyek yang diteliti. Dalam penelitian ini penulis memperoleh data dengan menggunakan kuesioner yang telah diberi skor, dimana data tersebut nantinya akan dihitung secara statistik.

\section{Tempat dan Waktu Penelitian}

Penelitian ini dilakukan di Komisi Pemilihan Umum (KPU) Kota Tangerang di Jl. Nyimas Melati I No. 16 Kec Tangerang Kota Tangerang. Peneliti memilih tempat KPU Kota Tangerang dikarenakan KPU Kota Tangerang pelaksana pemilu di Kota Tangerang. Waktu yang digunakan dalam penelitian ini yaitu selama enam bulan terhitung dari bulan Februari 2017 sampai dengan Juli 2017.

\section{Populasi Penelitian}

Populasi dalam penelitian ini adalah keseluruhan komisioner KPU Kota Tangerang sebanyak 5 orang dan sekretariat KPU Kota Tangerang sebanyak 20 orang hingga KPU Tingkat Kecamatan di Kota Tangerang atau PPK (Panitia Pemilihan Kecamatan) sebanyak
65 orang, jadi jumlah total keseluruhan populasinya sebanyak 90 orang.

\section{Sampel Penelitian}

Sampel dalam penelitian ini sebanyak 90 orang, yakni keseluruhan jumlah populasi diambil menjadi sampel, yaitu menggunakan Nonprobability sampling dengan cara Sampling jenuh yaitu teknik penentuan sampel bila anggota populasi digunakan sebagai sampel atau keseluruhan jumlah populasi sebagai jumlah keseluruhan sampel Sugiono (2012:9596) yaitu keseluruhan komisioner KPU Kota Tangerang sebanyak 5 orang dan secretariat KPU Kota Tangerang sebanyak 20 orang hingga KPU Tingkat Kecamatan di Kota Tangerang atau PPK (Panitia Pemilihan Kecamatan) sebanyak 65 orang

\section{Definisi Konseptual dan Operasional Variabel Tata Kelola Pemilihan (Variabel $\mathrm{X}_{1}$ )}

\section{1). Definisi Konseptual}

Tata Kelola Pemilih adalah hal-hal yang berkaitan dengan sistem hukum-hukum, dan faktor-faktor serta tindakan atau aktivitas pengelolaan yang bersifat mengarahkan, mengendalikan atau mempengaruhi urusan-urusan kependudukan berdasarkan kriteria pemilih yang sah atau wajib memilih dalam pemilu.

2). Definisi Operasional Tata Kelola Pemilihan

Operasionalisasi dari penelitian ini adalah dengan mengukur semua indicator menggunakan sekala Likers, dengan 5 jawaban, SS= Sangat Setuju (bobot nilai 5), ST= Setuju (bobot nilai 4), RG= Ragu-ragu (bobot nilai 3), TS= Tidak Setuju ((bobot nilai 2), STS= Sangat Tidak Setuju (bobot nilai 1) 
3). Kisi-kisi kuisioner

\begin{tabular}{|c|c|c|c|c|}
\hline VARIABEL & INDIKATOR & ITEM ANGKET & JML & ALAT UKUR \\
\hline \multirow{4}{*}{$\begin{array}{l}\text { TATA KELOLA } \\
\text { PEMILIH }\end{array}$} & $\begin{array}{l}\text { Dasar Hukum yang mengatur tata } \\
\text { kelolah pemilih }\end{array}$ & $1,2,3,4,5$ & 5 & \multirow{4}{*}{$\begin{array}{c}\text { Angket yang } \\
\text { menggunakan } \\
\text { skala Likers }\end{array}$} \\
\hline & Faktor internal dan ekternal & $6,7,8,9,10$ & 5 & \\
\hline & Aktivitas pengelolaan & $11,12,13,14,15$ & 5 & \\
\hline & Kependudukan dan Pemilih & $16,17,18,19,20$ & 5 & \\
\hline
\end{tabular}

\section{Penyiapan Logistik (Variabel $\mathrm{X}_{2}$ )}

1). Definisi Konseptual

penyiapan logistik pemilu adalah kesiapan dan tata cata atau mekanisme, penyelenggara pemilu dalam hal ini KPU pada proses pengadaan, pendistibusian, dan penggunaan suatu barang atau jasa (logistik) pemilu dengan terencana (sadar) sesuai dengan kebutuhan.
2). Definisi Operasional Penyiapan Logistik Operasionalisasi dari penelitian ini adalah dengan mengukur semua indicator menggunakan sekala Likers, dengan 5 jawaban, SS = Sangat Setuju (bobot nilai 5), ST= Setuju (bobot nilai 4), RG= Ragu-ragu (bobot nilai 3), TS= Tidak Setuju ((bobot nilai 2), STS= Sangat Tidak Setuju (bobot nilai 1)

\section{3). Kisi-kisi kuisioner}

\begin{tabular}{|c|c|c|c|c|}
\hline VARIABEL & INDIKATOR & ITEM ANGKET & JML & ALAT UKUR \\
\hline \multirow{4}{*}{$\begin{array}{l}\text { PENYIAPAN } \\
\text { LOGISTIK }\end{array}$} & 1. Kesiapan & $1,2,3,4,5$ & 5 & \multirow{4}{*}{$\begin{array}{c}\text { Angket yang } \\
\text { menggunakan } \\
\text { skala Likers }\end{array}$} \\
\hline & 2. Tata cara/mekanisme & $6,7,8,9,10$ & 5 & \\
\hline & 3. Pelaksana Pemilu & $11,12,13,14,15$ & 5 & \\
\hline & $\begin{array}{l}\text { 4. Pengadaan dan pendistribusian logistik } \\
\text { pemilu }\end{array}$ & $16,17,18,19,20$ & 5 & \\
\hline
\end{tabular}

\section{Efektivitas Pemilu Legislativ (Variabel Y)}

\section{1). Definisi Konseptual Efektivitas}

efektivitas pemilu adalah adanya suatu proses pemilu yang mudah, tidak rumit, tidak bertele-tele, ketepatan sosialisasi terhadap masyarakat sehingga mengakibatkan rendahnya tingkat golput atau tingginya tingkat partisifasi masyarakat/ efesiensi dalam menentukan suaranya dan rendahnya kecurangan pada pemilu se- hingga menjadikan pemilu yang berkualitas

2). Definisi Operasional Efektivitas

Operasionalisasi dari penelitian ini adalah dengan mengukur semua indicator menggunakan sekala Likers, dengan 5 jawaban, SS= Sangat Setuju (bobot nilai 5), ST= Setuju (bobot nilai 4), RG= Ragu-ragu (bobot nilai 3), TS= Tidak Setuju ((bobot nilai 2), STS= Sangat Tidak Setuju (bobot nilai 1)

3). Kisi-kisi kuisioner

\begin{tabular}{|c|l|c|c|c|} 
VARIABEL & \multicolumn{1}{|c|}{ INDIKATOR } & ITEM ANGKET & JML & ALAT UKUR \\
\hline \multirow{4}{*}{$\begin{array}{c}\text { EFEKTIVITAS } \\
\text { PEMILU }\end{array}$} & $\mathbf{1 .}$ Proses Mudah & $1,2,3,4,5$ & 5 & \\
\cline { 2 - 5 } & $\mathbf{2 .} \quad$ Ketepatan & $6,7,8,9,10$ & 5 & \multirow{2}{*}{$\begin{array}{c}\text { Angket yang } \\
\text { menggunakan } \\
\text { skala Likers }\end{array}$} \\
\cline { 2 - 5 } & $\begin{array}{l}\mathbf{3 .} \text { Tingginya Partisipasi Masyarakat / } \\
\text { Efesiensi }\end{array}$ & $11,12,13,14,15$ & 5 & \\
\cline { 2 - 5 } & $\mathbf{4 .} \quad$ Kualitas Pemilu & $16,17,18,19,20$ & 5 & \\
\hline
\end{tabular}




\section{PEMBAHASAN DAN HASIL PENELITIAN}

\section{Deskripsi Data Penelitian}

Pada bagian ini secara berturut-turut akan disajikan gambaran atau deskripsi dari data yang diperoleh berdasarkan penelitian yang dilakukan masing-masing untuk variable tata kelola pemilih, penyiapan logistik pemilu dan efektivitas pemilu.

Ketiga jenis data yang dideskripsikan ini diperoleh melalui angket berupa pertanyaanpertanyaan yang telah dirancang oleh peneliti berdasarkan indikator-indikatornya. Setelah pendeskripsian data, selanjutnya disajikan pula pengujian persyarat analisis, pengujian hipotesis dan dilanjutkan dengan tafsiran terhadap hasil pengujian hipotesis.

\section{Tata Kelola Pemilih $\left(\mathrm{X}_{1}\right)$}

Instrument yang dibuat untuk mengukur variable Tata Kelola Pemilih berbentuk pertanyaan-pertanyaan yang didasarkan pada skala likert dengan pemberian skor 5 respon sangat setuju, 4 setuju, 3 ragu-ragu, 2 tidak setuju dan 1 sangat tidak setuju. Pemberian skor ini untuk pernyataan positif dan sebaliknya bila berbentuk pernyataan negatif. Setelah melalui proses uji coba ternyata jumlah pertanyaan yang layak setelah dilihat validitas dan reliabilitasnya adalah semua butir pernyataan sebanyak 20 butir. Dengan demikian kemungkinan skor tertinggi 100 dan skor terendah adalah 20.

Dari data penelitian yang terkumpul menunjukkan bahwa rentangan skor efektivitas pemilu adalah skor tertinggi 94, terendah 61 selanjutnya diperoleh rata-rata (mean) 75.0889, nilai tengah (median) 75 , dan standar deviasi 8.43567 .

Tabel 1 Distribusi Frekuensi Tata Kelola Pemilih $\left(X_{1}\right)$

\begin{tabular}{|c|c|c|}
\hline $\begin{array}{c}\text { Tata Kelola } \\
\text { Pemilih (X1) }\end{array}$ & Frekuensi (f) & $\begin{array}{c}\text { Frekuensi } \\
\text { Relatif \% }\end{array}$ \\
\hline $60-65$ & 2 & 2.2 \\
\hline $66-70$ & 18 & 20 \\
\hline $71-75$ & 6 & 6.6 \\
\hline $76-80$ & 28 & 32.1 \\
\hline $81-85$ & 18 & 21 \\
\hline
\end{tabular}

\begin{tabular}{|c|c|c|}
\hline $86-90$ & 14 & 15.5 \\
\hline $91-95$ & 4 & 4.4 \\
\hline Jumlah & 90 & 100 \\
\hline
\end{tabular}

Berdasarkan hasil diatas, dapat disimpulkan bahwa skor Efektivitas Pemilu di KPU Kota Tangerang termasuk dalam kategori sedang, karena rata-rata diperoleh 78.4000 atau 52.2\% dari kemungkinan skor tertinggi yaitu 100\%.

\section{Penyiapan Logistik Pemilu $\left(\mathrm{X}_{2}\right)$}

Instrument yang dibuat untuk mengukur variable Penyiapan Logistik Pemilu berbentuk pertanyaan-pertanyaan yang didasarkan pada skala likert dengan pemberian skor 5 respon sangat setuju, 4 setuju, 3 ragu-ragu, 2 tidak setuju dan 1 sangat tidak setuju. Pemberian skor ini untuk pernyataan positif dan sebaliknya bila berbentuk pernyataan negative. Setelah melalui proses uji coba ternyata jumlah pertanyaan yang layak setelah dilihat validitas dan reliabilitasnya adalah semua butir pernyataan sebanyak 20 butir. Dengan demikian kemungkinan skor tertinggi 100 dan skor terendah adalah 20 .

Dari data penelitian yang terkumpul menunjukkan bahwa rentangan skor efektivitas pemilu adalah skor tertinggi 94 , terendah 61 selanjutnya diperoleh rata-rata (mean) 75.0889, nilai tengah (median) 75 , dan standar deviasi 8.43567 .

Tabel 2 Distribusi Frekuensi Penyiapan Logistik Pemilu $\left(\mathrm{X}_{2}\right)$

\begin{tabular}{|c|c|c|}
$\begin{array}{c}\text { Penyiapan } \\
\text { Logistik Pemilu } \\
\text { (X2) }\end{array}$ & Frekuensi (f) & $\begin{array}{c}\text { Frekuensi } \\
\text { Relatif \% }\end{array}$ \\
\hline $60-65$ & 16 & 17.7 \\
\hline $66-70$ & 1 & 1.1 \\
\hline $71-75$ & 26 & 28.9 \\
\hline $76-80$ & 17 & 18.9 \\
\hline $81-85$ & 22 & 22.2 \\
\hline $86-90$ & 2 & 2.2 \\
\hline $91-95$ & 2 & 2.2 \\
\hline Jumlah & 90 & 100 \\
\hline
\end{tabular}

Berdasarkan hasil diatas, dapat disimpulkan bahwa skor Efektivitas Pemilu di KPU Kota 
Tangerang termasuk dalam kategori sedang, karena rata-rata diperoleh 76.8111 atau 32,2\% dari kemungkinan skor tertinggi yaitu 100\%.

\section{Efektivitas Pemilu}

Instrument yang dibuat untuk mengukur variable efektivitas Pemilu berbentuk pertanyaan-pertanyaan yang didasarkan pada skala likert dengan pemberian skor 5 respon sangat setuju, 4 setuju, 3 ragu-ragu, 2 tidak setuju dan 1 sangat tidak setuju. Pemberian skor ini untuk pernyataan positif dan sebaliknya bila berbentuk pernyataan negatif. Setelah melalui proses uji coba ternyata jumlah pertanyaan yang layak setelah dilihat validitas dan reliabilitasnya adalah semua butir pernyataan sebanyak 20 butir. Dengan demikian kemungkinan skor tertinggi 100 dan skor terendah adalah 20 .

Dari data penelitian yang terkumpul menunjukkan bahwa rentangan skor efektivitas pemilu adalah skor tertinggi 95, terendah 65 selanjutnya diperoleh rata-rata (mean) 79.7333, nilai tengah (median) 80, dan standar deviasi 7.49502

Tabel 3 Distribusi Frekuensi Efektivitas Pemilu (Y)

\begin{tabular}{|c|c|c|}
\hline $\begin{array}{c}\text { Efektivitas } \\
\text { Pemilu (Y) }\end{array}$ & Frekuensi (f) & $\begin{array}{c}\text { Frekuensi } \\
\text { Relatif \% }\end{array}$ \\
\hline $60-65$ & 6 & 6.7 \\
\hline $66-70$ & 7 & 7.8 \\
\hline $71-75$ & 12 & 13.1 \\
\hline $76-80$ & 22 & 24.3 \\
\hline $81-85$ & 24 & 26.6 \\
\hline $86-90$ & 13 & 14.3 \\
\hline $91-95$ & 6 & 6.6 \\
\hline Jumlah & 90 & 100 \\
\hline
\end{tabular}

Berdasarkan hasil diatas, dapat disimpulkan bahwa skor Efektivitas Pemilu di KPU Kota Tangerang termasuk dalam kategori sedang, karena rata-rata diperoleh 79.7333 atau 41,1\% dari kemungkinan skor tertinggi yaitu 100\%.

\section{Uji Asumsi Analisis}

Uji asumsi dasar yang digunakan menge- tahui pola dan varian. Apakah populasi atau data berdistribusi normal atau tidak, atau juga uji dapat digunakan untuk mengetahui apakah polulasi mempunyai beberapa varian yang sama. Dalam uji asumsi dasar yang digunakan adalah uji normalitas dan uji homogenitas.

\section{a. Uji Normalitas}

Uji Normalitas digunakan untuk mengetahui apakah populasi data berdistribusi normal atau tidak. Dalam uji normalitas ini yang digunakan uji One Sample Kolmogorov-Smirnov dengan menggunakan taraf signifikansi 0,05 . Data dinyatakan berdistribusi normal jika signifikansi lebih besar dari 5\% atau 0,05. Untuk menguji uji normalitas menggunakan SPSS versi 20.0

\section{Tata Kelola Pemilih $\left(\mathrm{X}_{1}\right)$}

Uji normalitas merupakan bagian dari uji perasyarat analisis ststistik atau analisis uji asumsi dasar. Uji asumsi dasar adalah syarat yang harus dipenuhi sebelum data yang ada di uji dengan uji ststistik yang sesungguhnya. Hasil pengujian normalitas efektivitas pemilu dengan SPSS diperoleh tabel sebagai berikut.

Tabel 4 Hasil Uji Normalitas dengan SPSS Tata Kelola Pemilih $\left(\mathrm{X}_{1}\right)$

Tests of Normality

Kolmogorov-Smirnov ${ }^{\mathrm{a}} \quad$ Shapiro-Wilk \begin{tabular}{|l|l|l|l|l|l|}
\hline Statistic & df & Sig. & Statistic & df & Sig. \\
\hline
\end{tabular}

Tata Kelola

Pemilih

\begin{tabular}{l|l|l|l|l|l|}
.128 & 90 & .001 & .949 & 90 & .001 \\
\hline
\end{tabular}

a. Lilliefors Significance Correction

Berdasarkan data di atas dapat dianalisis sebagai berikut:

a. Membuat hipotesis dalam uraian kalimat

Ho : Data berdistribusi normal

$\mathrm{Ha}$ : Data tidak berdistribusi normal

b. Kaidak pengujian

Kriteria pengujian yang diambil berdasarkan perbandingan antara $\mathrm{D}$ hitung dan $\mathrm{D}$ tabel adalah sebagai berikut:

- Ho diterima, jika $\mathrm{D}$ hitung $\leq \mathrm{D}$ tabel (a, $\mathrm{n} 1, \mathrm{n} 2)$

- Ho ditolah, jika $\mathrm{D}_{\text {hitung }}>\mathrm{D}$ tabel (a, $\mathrm{n} 1$, $\mathrm{n} 2$ ) 
- Membandingkan $\mathrm{D}_{\text {tabel }}$ dan $\mathrm{D}_{\text {hitung }}$

- Dari data test statsitik nilai $\mathrm{D}$ hitung $=$ 0,128

- Dari tabel Kolmogorov-Smirnov nilai $\mathrm{D}_{\text {tabel }}=0,135$

- Ternyata $\mathrm{D}$ hitung $=0,128<\mathrm{D}$ tabel $=0,135$. Sehingga Ho diterima, maka keputusan hipotesisnya data berdistribusi normal

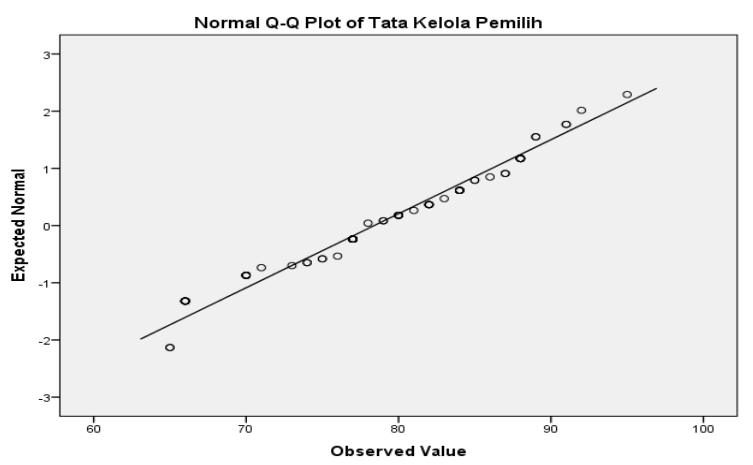

Sumber: Output Data Program SPSS Versi 20

Gambar 1 Normal Q-Q

Plot Tata Kelola Pemilih (X1)

Pada diagram Normal Q-Q Plot, dikatakan memenuhi asumsi normalitas jika diagram menunjukkan plot-plot mengikuti alur garis lurus.

\section{Penyiapan Logistik Pemilu $\left(X_{2}\right)$}

Uji normalitas merupakan bagian dari uji perasyarat analisis ststistik atau analisis uji asumsi dasar. Uji asumsi dasar adalah syarat yang harus dipenuhi sebelum data yang ada di uji dengan uji ststistik yang sesungguhnya. Hasil pengujian normalitas efektivitas pemilu dengan SPSS diperoleh tabel sebagai berikut.

Tabel 5 Hasil Uji Normalitas dengan SPSS Penyiapan Logistik Pemilu $\left(\mathrm{X}_{2}\right)$

Tests of Normality

\begin{tabular}{|l|r|r|r|r|r|r|}
\hline & \multicolumn{3}{|c|}{ Kolmogorov-Smirnov } & \multicolumn{3}{|c|}{ Shapiro-Wilk } \\
\cline { 2 - 7 } & Statistic & df & Sig. & Statistic & df & Sig. \\
\hline $\begin{array}{l}\text { Penyiapan } \\
\text { Logistik }\end{array}$ & .124 & 90 & .002 & .837 & 90 & .000 \\
\hline
\end{tabular}

Berdasarkan data di atas dapat dianalisis sebagai berikut:

- Dari data test statsitik nilai $\mathrm{D}_{\text {hitung }}=$ 0,124

- Dari tabel Kolmogorov-Smirnov nilai $\mathrm{D}_{\text {tabel }}=0,135$

- $\quad$ Ternyata $\mathrm{D}_{\text {hitung }}=0,124<\mathrm{D}_{\text {tabel }}=0,135$. Sehingga Ho diterima, maka keputusan hipotesisnya data berdistribusi normal.

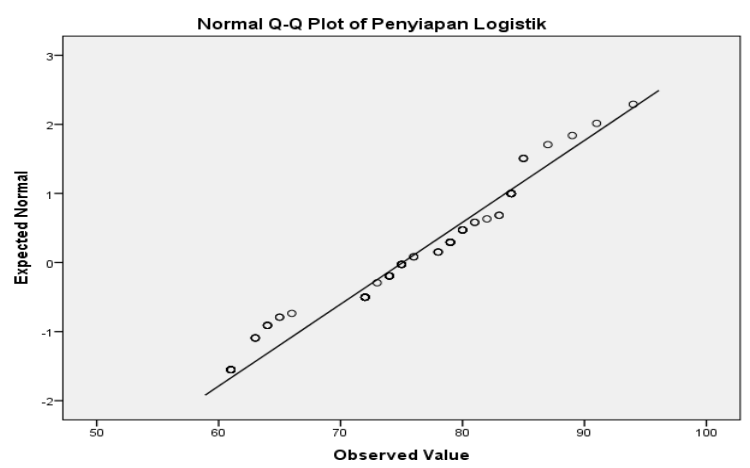

Sumber: Output Data Program SPSS Versi 20

Gambar 2 Normal Q-Q

Plot Penyiapan Logistik Pemilu $\left(\mathrm{X}_{2}\right)$

Pada diagram Normal Q-Q Plot, dikatakan memenuhi asumsi normalitas jika diagram menunjukkan plot-plot mengikuti alur garis lurus.

\section{Efektivitas Pemilu (Y)}

Uji normalitas merupakan bagian dari uji perasyarat analisis ststistik atau analisis uji asumsi dasar. Uji asumsi dasar adalah syarat yang harus dipenuhi sebelum data yang ada di uji dengan uji ststistik yang sesungguhnya. Hasil pengujian normalitas efektivitas pemilu dengan SPSS diperoleh tabel sebagai berikut.

Tabel 6 Hasil Uji Normalitas dengan SPSS

Efektivitas Pemilu (Y)

Tests of Normality

Kolmogorov-Smirnov ${ }^{\mathrm{a}}$ Shapiro-Wilk

\begin{tabular}{|l|c|c|c|c|c|}
\hline Statistic & df & Sig. & Statistic & df & Sig. \\
\hline
\end{tabular}

Efektivitas

Pemilu

a. Lilliefors Significance Correction 
Berdasarkan data di atas dapat dianalisis sebagai berikut:

- Dari data test statsitik nilai $\mathrm{D}$ hitung $=$ 0,103

- Dari tabel Kolmogorov-Smirnov nilai $\mathrm{D}_{\text {tabel }}=0,135$

- Ternyata $\mathrm{D}_{\text {hitung }}=0,103<\mathrm{D}_{\text {tabel }}=0,135$. Sehingga Ho diterima, maka keputusan hipotesisnya data berdistribusi normal

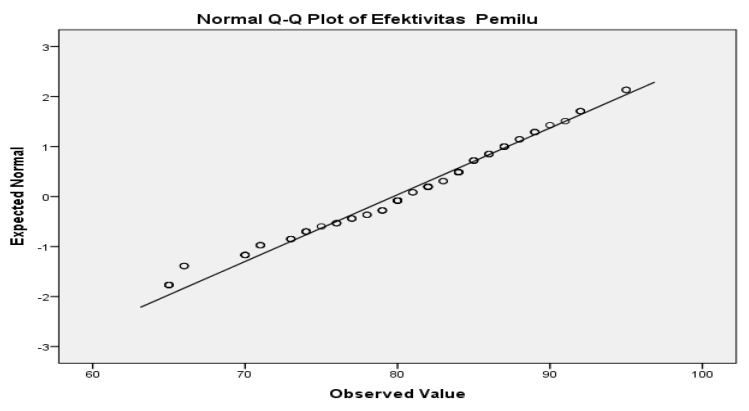

Sumber: Output Data Program SPSS Versi 20

Gambar 3 Normal Q-Q

Plot Efektifitas Pemilu (Y)

Pada diagram Normal Q-Q Plot, dikatakan memenuhi asumsi normalitas jika diagram menunjukan plot-plot mengikuti alur garis lurus.

\section{b. Uji Homogenitas}

Uji homogenitas dimaksudkan untuk memperlihatkan bahwa dua atau lebih kelompok data sampel berasal dari populasi yang memiliki variansi yang sama.

Teknik pengujian yang digunakan adalah uji bartlet. Uji bartlet dilakukan dengan menghitung $x^{2}$. Harga $x^{2}$ yang diperoleh dari perhitungan ( $\mathrm{x}^{2}$ hitung $)$, selanjutnya dibandingkan dengan $\mathrm{x}^{2}$ tabel $\left(\mathrm{X}^{2}\right.$ tabel), bila $\mathrm{x}^{2}$ hitung $<\mathrm{x}^{2}$ tabel , maka hipotesis nol diteima. Artinya data berasal dari populasi yang homogen. Perhitungan uji homogenitas ini dengan menggunakan software SPSS versi 20.
Tabel 7 Uji HomogenitasVariabel Efektivitas Pemilu (Y) dengan

Variabel Tata Kelola Pemilih $\left(\mathrm{X}_{1}\right)$

Test of Homogeneity of Variances Efektivitas Pemilu

\begin{tabular}{|l|l|l|l}
\hline Levene Statistic & df1 & df2 & Sig. \\
\hline
\end{tabular}

1.845

\begin{tabular}{l|l|l}
14 & 66 & .050
\end{tabular}

Dari tabel 7 Test of Homogeneity of Variances dapat diketahui kedua variabel antara efektivitas pemilu dengan variable tata kelola pemilih terlihat signifikasi sebesar 0,050 . Nilai ini menujukan bahwa nilai $s i g>a=0,050>0,05$ maka dapat disimpulkan kedua kelompok data mempunyai varian yang sama

Tabel 8 Uji HomogenitasVariabel Efektivitas Pemilu (Y) dengan

Variabel Penyiapan Logistik Pemilu $\mathrm{X}_{2}$ Test of Homogeneity of Variances Efektivitas Pemilu

\begin{tabular}{|c|c|c|c|} 
Levene Statistic & df1 & df2 & Sig.
\end{tabular}

.965

\begin{tabular}{l|l}
14 & 68
\end{tabular}

.497

Dari tabel Test of Homogeneity of Variances dapat diketahui kedua variabel antara efektivitas pemilu dengan variable penyiapan logistik pemilu terlihat signifikasi sebesar 0,497 . Nilai ini menujukan bahwa nilai sig $>a=0,497>0,05$ maka dapat disimpulkan kedua kelompok data mempunyai varian yang sama.

\section{Pengujian Hipotesis}

Setelah dilakukan pengujian instrument (uji validitas, uji reliabilitas dan uji asumsi statisik), di atas maka langkah selanjutnya pengujian hipotesis, yaitu utuk mengetahui pengaruh antara kedua variable independen terhadap satu variable dependen yang dikemukakan dalam rumusan masalah. Sesuai dengan tahapantahapan pada metode penelitian Bab III, maka data primer yang telah ditabulasi dan diolah dengan menggunakan analisa Program SPSS 20, peneliti uraikan hasilnya sebagai berikut: 


\section{Pengaruh Tata Kelolah Pemilih $\left(X_{1}\right)$ Terhadap Efektivitas Pemilu (Y)}

Hasil penelitian Pengaruh Tata Kelolah Pemilih $\left(\mathrm{X}_{1}\right)$ Terhadap Efektivitas Pemilu (Y), setelah melalui tahapan pengujian statistic dengan dengan olah data SPSS 20 hasilnya dapat dideskripsikan lebih rinci sebagai berikut:

\section{a. Uji Korelasi Sederhana}

Tabel 9 Hasil Uji $\mathbf{r}_{\text {hitung }}$ Variabel $\mathrm{X}_{1}$ Terhadap Variabel Y

Correlations

\begin{tabular}{|c|c|c|c|}
\hline & & $\begin{array}{c}\text { Efektivitas } \\
\text { Pemilu }\end{array}$ & $\begin{array}{c}\text { Tata } \\
\text { Kelola } \\
\text { Pemilih }\end{array}$ \\
\hline \multirow{2}{*}{$\begin{array}{l}\text { Pearson } \\
\text { Correlation }\end{array}$} & Efektivitas Pemilu (Y) & 1.000 & .315 \\
\hline & Tata Kelola Pemilih $\left(\mathrm{X}_{1}\right)$ & .315 & 1.000 \\
\hline \multirow{2}{*}{$\begin{array}{l}\text { Sig. } \\
\text { (1-tailed) }\end{array}$} & Efektivitas Pemilu (Y) & & .001 \\
\hline & Tata Kelola Pemilih $\left(\mathrm{X}_{1}\right)$ & .001 & \\
\hline \multirow{2}{*}{ N } & Efektivitas Pemilu (Y) & 90 & 90 \\
\hline & Tata Kelola Pemilih $\left(X_{1}\right)$ & 90 & 90 \\
\hline
\end{tabular}

Data pada tabel 9 di atas, menujukan skor nilai korelasi sebesar 0,315 . Hasil ini menunjukkan adanya pengaruh yang positif dan signifikan antara Tata Kelolah Pemilih (X1) Terhadap Efektivitas Pemilu Gubernur dan Wakil Gubernur Banten Tahun 2017 (Y). Untuk mengetahui apakah korelasi tersebut dapat digeneralisasikan atau tidak, maka perlu dibandingkan dengan nilai rtabeldengan taraf kesalahan 5\% (derajat kepercayaan 95\%). Untuk harga $\mathrm{n}=90$ pada tabel nilai-nilai $\mathrm{r}$ product moment menunjukkan skor nilai $\mathrm{r}_{\text {tabel }}$ sebesar 0,207 . Ternyata harga $\mathrm{r}_{\text {hitung }}(0,315)>$ harga $r_{\text {tabel }}(0,207)$, sehingga Ho ditolak dan Ha diterima. Jadi kesimpulannya ada pengaruh positif dan signifikan antara Tata Kelolah Pemilih (X1) Terhadap Efektivitas Pemilu Gubernur dan Wakil Gubernur Banten Tahun 2017 (Y) di KPU Kota Tangerang. Jika berpedoman pada interpretasi koefesien korelasi, skor nilai korelasi 0.315 berada pada interval nilai 0.200-0.399 yang artinya mempunyai tingkat hubungan rendah.

\section{b. Uji Hipotesis $\left(\mathbf{t}_{\text {hitung }}\right)$}

Hasil pengolahan data statistik $\mathrm{t}_{\text {hitung }}$ pada ini dapat dilihat pada tabel 10 di bawah ini

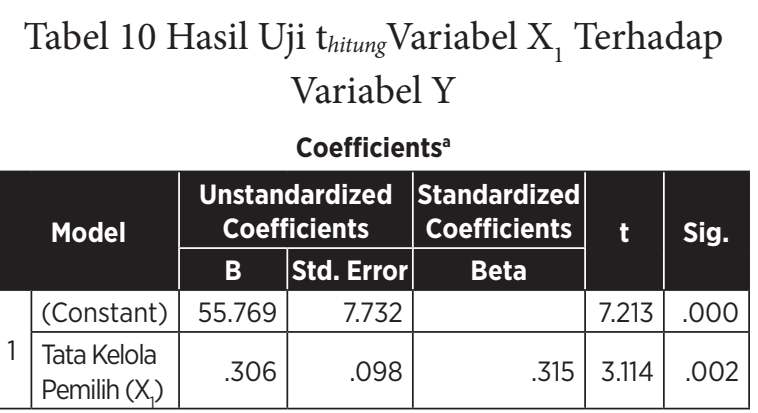

a. Dependent Variable: Efektivitas Pemilu

Hasil perhitungan SPSS pada tabel 10, menujukan nilai $t_{\text {hitung }}$ untuk Tata Kelolah Pemilih $\left(\mathrm{X}_{1}\right)$ diperoleh nilai sebesar 3.114. Adapun harga $\mathrm{t}_{\text {tabel }}$ untuk $\mathrm{dk}(90-2=88)$ dalam nilai-nilai distribusi t untuk uji dua pihak taraf signifikan 0.05 menunjukkan skor nilai 1.980. Hal ini membuktikan bahwa $t_{\text {hitung }}(3.114)>\mathrm{t}_{\text {tabel }}$ (1.980). Dengan demikian Ho ditolak dan $\mathrm{Ha}$ diterima. Dapat ditarik kesimpulan bahwa terdapat pengaruh yang signifikan antara Tata Kelolah Pemilih $\left(\mathrm{X}_{1}\right)$ Terhadap Efektivitas Pemilu Gubernur dan Wakil Gubernur Banten Tahun 2017 (Y) di KPU Kota Tangerang.

\section{c. Uji Regresi Linier}

Analisis regresi dibuat untuk mengetahui antara variable indevenden dengan variable dependen. Dalam pengujian hipotesis ke - 1 hasil uji regresi liniernya dapat dilihat pada tabel 11 di bawah ini

Tabel 11 Hasil Uji Regresi Linier Variabel X Terhadap Variabel Y

Coefficients $^{a}$

\begin{tabular}{|c|c|c|c|c|c|c|}
\hline & \multirow[t]{2}{*}{ Model } & \multicolumn{2}{|c|}{$\begin{array}{c}\text { Unstandardized } \\
\text { Coefficients }\end{array}$} & \multirow{2}{*}{\begin{tabular}{|c|}
$\begin{array}{c}\text { Standardized } \\
\text { Coefficients }\end{array}$ \\
Beta \\
\end{tabular}} & \multirow[t]{2}{*}{$\mathbf{t}$} & \multirow[t]{2}{*}{ Sig. } \\
\hline & & B & Std. Error & & & \\
\hline & (Constant) & 55.769 & 7.732 & & 7.213 & .000 \\
\hline 1 & $\begin{array}{l}\text { Tata Kelola } \\
\text { Pemilih } \\
\left(\mathrm{X}_{1}\right) \\
\end{array}$ & .306 & .098 & .315 & 3.114 & .002 \\
\hline
\end{tabular}

a. Dependent Variable: Efektivitas Pemilu

Pada tabel di atas, menunjukan hasil perhitungan regresi linier sederhana nilai koefesien a dan b sebagai berikut : $\hat{Y}=55.769+0.306 . X$ 
Persamaan regresi yang digunakan untuk melakukan prediksi (ramalan) dalam variable dependen akan terjadi bila dalam variable indevenden ditetapkan. Jadi bila Tata Kelolah Pemilih $\left(\mathrm{X}_{1}\right)$ di KPU meningkat/ ditingkatkan hingga mendapat nilai 1, maka Efektivitas Pemilu Gubernur dan Wakil Gubernur Banten Tahun 2017 (Y) menjadi : $\hat{Y}=55.769+0.306$. $1=56.075$

Jadi diperkirakan Efektivitas Pemilu Gubernur dan Wakil Gubernur Banten Tahun 2017 akan meningkat sebesar 56.075. Dengan demikian, Efektivitas Pemilu Gubernur dan Wakil Gubernur Banten Tahun 2017 akan naik, bila Tata Kelolah Pemilih lebih meningkat. Hal ini membuktikan bahwa variable indevenden $\mathrm{X}_{1}$ (Tata Kelola Pemilih) searah terhadap naiknya turunnya variable dependent Y (Efektivitas Pemilu Gubernur dan Wakil Gubernur Banten Tahun 2017). Untuk lebih jelasnya dapat digambarkan dalam diagram Normal P-P Plot Regresi Sederhana sebagai berikut:

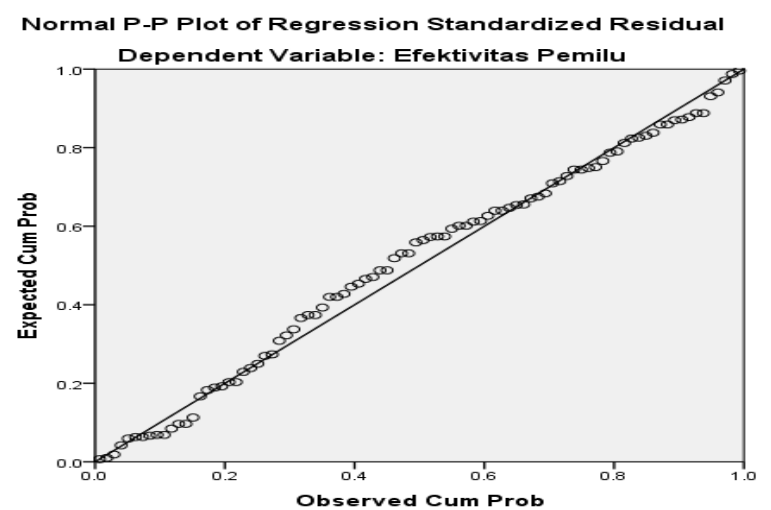

Sumber: Output Data Program SPSS Versi 20

Gambar 4

Garis Normal P-P Plot Regresi Linier

Sederhana Variabel X Terhadap Variabel Y

Nilai Plot yang berada pada garis normal di atas, menunjukan pada gerafik terlihat titiktitik menyebar disekitar garis diagonal serta penyebarannya ada disekitar garis diagonal. Artinya normalitas residu dari persamaan regresi linier tersebut terdistribusi normal.

\section{Pengaruh Penyiapan Logistik Pemilu} $\left(\mathrm{X}_{2}\right)$ Terhadap Efektivitas Pemilu (Y)

Analisis selanjutnya dilakukan dengan cara yang sama seperti pada pengujian hipotesis ke1. Melalui tahapan pengujian statistik, maka Pengaruh Penyiapan Logistik Pemilu $\left(\mathrm{X}_{2}\right)$ Terhadap Efektivitas Pemilu Gubernur dan Wakil Gubernur Banten Tahun 2017 (Y) diperoleh hasil sebagai berikut:

\section{a. Uji Korelasi Sederhana}

Tabel 12 Hasil Uji r hitung Variabel $\mathrm{X}_{2}$ Terhadap Variabel Y

Correlations

\begin{tabular}{|l|l|r|r|}
\multicolumn{2}{|c|}{} & $\begin{array}{r}\text { Efektivitas } \\
\text { Pemilu }(Y)\end{array}$ & $\begin{array}{l}\text { Penyiapan } \\
\text { logistik } \\
\text { Pemilu }\left(\mathrm{X}_{2}\right)\end{array}$ \\
\hline \multirow{2}{*}{$\begin{array}{l}\text { Pearson } \\
\text { Correlation }\end{array}$} & Efektivitas Pemilu $(\mathrm{Y})$ & 1.000 & .224 \\
\cline { 2 - 4 } & $\begin{array}{l}\text { Penyiapan logistik } \\
\text { Pemilu }\left(\mathrm{X}_{2}\right)\end{array}$ & .224 & 1.000 \\
\hline \multirow{2}{*}{$\begin{array}{l}\text { Sig. } \\
\text { (1-tailed) }\end{array}$} & Efektivitas Pemilu $(\mathrm{Y})$ &. & .017 \\
\cline { 2 - 4 } & $\begin{array}{l}\text { Penyiapan logistik } \\
\text { Pemilu }\left(\mathrm{X}_{2}\right)\end{array}$ & .017 & \\
\hline \multirow{2}{*}{$\mathrm{N}$} & Efektivitas Pemilu $(\mathrm{Y})$ & 90 & 90 \\
\cline { 2 - 4 } & $\begin{array}{l}\text { Penyiapan logistik } \\
\text { Pemilu }\left(\mathrm{X}_{2}\right)\end{array}$ & 90 & 90 \\
\hline
\end{tabular}

Pada tabel 12, terlihat bahwa uji $\mathrm{r}$ hitung antara variabel Penyiapan Logistik Pemilu $\left(\mathrm{X}_{2}\right)$ Terhadap Efektivitas Pemilu (Y) diperoleh skor korelasi sebesar 1.000. Hasil ini menujukan adanya pengaruh yang positif dan signifikan antara Penyiapan Logistik Pemilu $\left(\mathrm{X}_{2}\right)$ Terhadap Efektivitas Pemilu Gubernur dan Wakil Gubernur Banten Tahun 2017 (Y).

Ternyata harga $\mathrm{r}_{\text {hitung }}(1.000)>$ harga $\mathrm{r}_{\text {tabel }}$ $(0,207)$, sehingga Ho ditolak dan Ha diterima. Jadi kesimpulannya ada pengaruh positif dan signifikan antara Penyiapan Logistik Pemilu $\left(\mathrm{X}_{2}\right)$ Terhadap Efektivitas Pemilu Gubernur dan Wakil Gubernur Banten Tahun 2017 (Y) di KPU Kota Tangerang. Jika berpedoman pada interpretasi koefesien korelasi, skor nilai korelasi 1.000 berada pada interval nilai 0.800-1.000 yang artinya mempunyai tingkat hubungan sangat tinggi. 


\section{b. Uji Hipotesis $\left(\mathbf{t}_{\text {hitung }}\right)$}

Dalam pengujian hipotesis ke-2 ini, hasil pengolahan data statistik nilai thitung yang diperoleh dapat dilihat pada tabel 13 di bawah ini:

Tabel 13 Hasil Uji $t_{\text {hitung }}$ Variabel $\mathrm{X}_{2}$ Terhadap Variabel Y

Coefficients $^{\mathrm{a}}$

\begin{tabular}{|c|c|c|c|c|c|c|}
\hline & \multirow{2}{*}{ Model } & \multicolumn{2}{|c|}{$\begin{array}{c}\text { Unstandardized } \\
\text { Coefficients }\end{array}$} & \multirow{2}{*}{$\begin{array}{c}\begin{array}{c}\text { Standardized } \\
\text { Coefficients }\end{array} \\
\text { Beta }\end{array}$} & \multirow{2}{*}{$\mathbf{T}$} & \multirow{2}{*}{ Sig. } \\
\hline & & B & $\begin{array}{l}\text { Std. } \\
\text { Error }\end{array}$ & & & \\
\hline \multirow[b]{2}{*}{1} & (Constant) & 64.781 & 6.974 & & 9.289 & .000 \\
\hline & $\begin{array}{l}\text { Penyiapan } \\
\text { logistik } \\
\text { Pemilu }\left(X_{2}\right)\end{array}$ & .199 & .092 & .224 & 2.157 & .034 \\
\hline
\end{tabular}

a. Dependent Variable: Efektivitas Pemilu (Y)

Hasil perhitungan SPSS pada tabel 13, menunjukkan nilai $t_{\text {hitung }}$ untuk Penyiapan Logistik Pemilu $\left(\mathrm{X}_{2}\right)$ diperoleh nilai sebesar 2157. Adapun harga $\mathrm{t}_{\text {tabel }}$ untuk dk $(90-2=88)$ dalam nilai-nilai distribusi t untuk uji dua pihak taraf signifikan 0.05 menunjukkan skor nilai 1.980 . Hal ini membuktikan bahwa $\mathrm{t}_{\text {hitung }}(2.157)>\mathrm{t}_{\text {tabel }}$ (1.980). Dengan demikian Ho ditolak dan Ha diterima. Dapat ditarik kesimpulan bahwa terdapat pengaruh yang signifikan antara Penyiapan Logistik Pemilu $\left(\mathrm{X}_{2}\right)$ Terhadap Efektivitas Pemilu Gubernur dan Wakil Gubernur Banten Tahun 2017 (Y) di KPU Kota Tangerang.

\section{c. Uji Regresi Linier}

Dalam pengujian hipotesis ke-2 hasil uji regresi liniernya dapat dilihat pada tabel di bawah ini

Tabel 14

Hasil Uji Regresi Linier Variabel $\mathrm{X}_{2}$ Terhadap Variabel Y

Coefficients $^{\mathrm{a}}$

\begin{tabular}{|c|c|c|c|c|c|c|}
\hline & \multirow[t]{2}{*}{ Model } & \multicolumn{2}{|c|}{$\begin{array}{c}\text { Unstandardized } \\
\text { Coefficients }\end{array}$} & \multirow{2}{*}{$\begin{array}{c}\begin{array}{c}\text { Standardized } \\
\text { Coefficients }\end{array} \\
\text { Beta }\end{array}$} & \multirow[t]{2}{*}{$\mathbf{t}$} & \multirow[t]{2}{*}{ Sig. } \\
\hline & & B & Std. Error & & & \\
\hline & (Constant) & 64.781 & 6.974 & & 9.289 & .000 \\
\hline 1 & $\begin{array}{l}\text { Penyiapan } \\
\text { logistik } \\
\text { Pemilu }\left(X_{2}\right)\end{array}$ & .199 & .092 & .224 & 2.157 & .034 \\
\hline
\end{tabular}

a. Dependent Variable: Efektivitas Pemilu (Y)
Pada tabel 14 di atas, menunjukan hasil perhitungan regresi linier sederhana nilai koefesien a dan b sebagai berikut :

$\hat{\mathrm{Y}}=64.781+0.199 . \mathrm{X}$

Persamaan regresi yang digunakan untuk melakukan prediksi (ramalan) dalam variable dependen akan terjadi bila dalam variable indevenden ditetapkan. Jadi bila Penyiapan Logistik Pemilu $\left(\mathrm{X}_{2}\right)$ di KPU meningkat/ ditingkatkan hingga mendapat nilai 1 , maka Efektivitas Pemilu Gubernur dan Wakil Gubernur Banten Tahun 2017 (Y) menjadi :

$$
\hat{\mathrm{Y}}=64.781+0.199 .1=64.980
$$

Jadi diperkirakan Efektivitas Pemilu Gubernur dan Wakil Gubernur Banten Tahun 2017 akan meningkat sebesar 64.980. Dengan demikian, Efektivitas Pemilu Gubernur dan Wakil Gubernur Banten Tahun 2017 akan naik, bila Penyiapan Logistik Pemilu lebih meningkat. Hal ini membuktikan bahwa variable indevenden $\mathrm{X}_{2}$ (Penyiapan Logistik Pemilu) searah terhadap naiknya turunnya variable dependent Y (Efektivitas Pemilu Gubernur dan Wakil Gubernur Banten Tahun 2017). Untuk lebih jelasnya dapat digambarkan dalam diagram Normal P-P Plot Regresi Sederhana sebagai berikut:

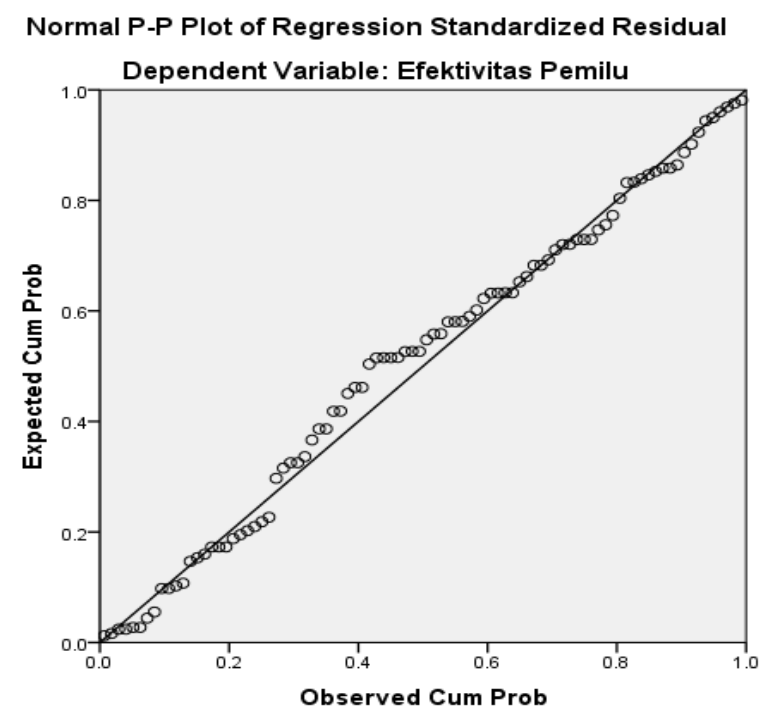

Sumber: Output Data Program SPSS Versi 20

Gambar 5

Garis Normal P-P Plot Regresi Linier Sederhana Variabel $X_{1}$ Terhadap Variabel Y 
Nilai Plot yang berada pada garis normal di atas, menunjukan pada gerafik terlihat titiktitik menyebar disekitar garis diagonal serta penyebarannya ada disekitar garis diagonal. Artinya normalitas residu dari persamaan regresi linier tersebut terdistribusi normal.

\section{Pengaruh Tata Kelola Pemilih $\left(X_{1}\right)$ Penyiapan Logistik Pemilu $\left(\mathrm{X}_{2}\right)$ Terhadap Efektivitas Pemilu (Y)}

\section{a. Uji Korelasi Berganda}

Setelah data ketiga variable dirangkum dalam tabel tabulasi dan dianalisis melalui hasil uji korelasi berganda, maka pengujian hipotesis ke-3 ini hasilnya dapat dilihat pada tabel di bawah ini.

Tabel 15

Hasil Uji Korelasi Berganda Variabel X Variabel $\mathrm{X}_{2}$ Terhadap Variabel Y

\begin{tabular}{|l|r|r|r|r|r|}
\hline Model & R & R Square & $\begin{array}{c}\text { Adjusted R } \\
\text { Square }\end{array}$ & $\begin{array}{c}\text { Std. Error of } \\
\text { the Estimate }\end{array}$ & $\begin{array}{c}\text { Durbin- } \\
\text { Watson }\end{array}$ \\
\hline 1 & $.329^{\mathrm{a}}$ & .108 & .088 & 7.15928 & 1.545 \\
\hline
\end{tabular}

a. Predictors: (Constant), Penyiapan logistik Pemilu, Tata Kelola Pemilih b. Dependent Variable: Efektivitas Pemilu

Nilai korelasi berganda (R) pada tabel 15 di atas menunjukan hasil korelasi sebesar 0.329. Jadi terdapat korelasi yang positif antara tata kelola pemilih dan penyiapan logistik pemilu secara bersama-sama terhadap efektivitas Pemilu Gubernur dan Wakil Gubernur Banten 2017. Hubungan ini secara kualitatif dapat dinyatakan lemah dalam arti searah dengan variable lainnya. Hal ini membuktikan adanya pengaruh yang lemah antara Tata Kelola Pemilih $\left(\mathrm{X}_{1}\right)$ dan Penyiapan Logistik Pemilu $\left(\mathrm{X}_{2}\right)$ terhadap Efektivitas Pemilu Gubernur dan Wakil Gubernur Banten Tahun 2017 (Y), berarti adanya faktor lain yang lebih mempengaruhi efektivitas Pemilu Gubernur dan Wakil Gubernur Banten Tahun 2017 di KPU Kota Tangerang.

\section{b. Uji $F_{\text {hitung }}$ (T-Test)}

Pada uji $F$ ini akan ditampilkan tabel analisis varian anova. Uji anova yaitu untuk mengetahui ada tidaknya hubungan dari ketiga variable. Oleh karena itu untuk mengetahui apakah koefesien korelasi berganda di atas dapat digeneralisasikan atau tidak, maka harus diuji signifikan dengan Uji Fhitung. Untuk mengetahui hasil $\mathrm{F}_{\text {hitung }}$ (Anova) dapat dilihat pada tabel di bawah ini:

Tabel 16

Hasil Uji Fhitung Variabel $X_{1}$ Variabel $X_{2}$ Terhadap Variabel Y

\begin{tabular}{|c|c|c|c|c|c|c|}
\hline \multicolumn{7}{|c|}{ ANOVA $^{a}$} \\
\hline \multicolumn{2}{|c|}{ Model } & Sum of & df & Mean & $F$ & Sig. \\
\hline \multirow{3}{*}{1} & Regression & 540.390 & 2 & 270.195 & 5.272 & $.007^{\mathrm{b}}$ \\
\hline & Residual & 4459.210 & 87 & 51.255 & & \\
\hline & Total & 4999.600 & 89 & & & \\
\hline
\end{tabular}

a. Dependent Variable: Efektivitas Pemilu (Y)

b. Predictors: (Constant), Penyiapan logistik Pemilu $\left(X_{2}\right)$, Tata Kelola Pemilih $\left(X_{1}\right.$

Dari tabel 16, menunjukkan hasil uji Fhitung dengan analisis program SPSS versi 20, yakni $\mathrm{F}_{\text {hitung }}$ diperoleh skor nilai sebesar 5.272. Harga ini selanjutnya perlu dikonsultasikan dengan $\mathrm{F}_{\text {tabel }}$ dengan $\mathrm{dk}$ pembilang $=\mathrm{k}$ dan $\mathrm{dk}$ penyebut $=(n-k-1)$ dengan taraf kesalahan yang ditetapkan 5\% $(\alpha=0,05)$ untuk $\mathrm{n}=90$ adalah 1.39. Jadi $\mathrm{F}_{\text {hitung }}(5.272)>\mathrm{F}_{\text {tabel }}(1.39)$, maka dapat dinyatakan bahwa Tata Kelola Pemilih $\left(\mathrm{X}_{1}\right)$ dan Penyiapan Logistik Pemilu $\left(\mathrm{X}_{2}\right)$ secara bersamasama berpengaruh terhadap Efektivitas Pemilu Gubernur dan Wakil Gubernur Banten Tahun 2017 (Y).

Dengan demikian, rumusan hipotesis ketiga yang dinyatakan sebelumya "Terdapat pengaruh yang positif dan signifikan Tata Kelola Pemilih dan Penyiapan Logistik Pemilu terhadap Efektivitas Pemilu Gubernur dan Wakil Gubernur Banten 2017 di KPU Kota Tangerang", terbukti kebenarannya. 


\section{c. Uji Regresi Linier Berganda}

Pada korelasi ganda dapat dilanjutkan dengan regresi ganda. Regresi linier berganda atau regresi multiple-linier memiliki perbedaan pada variable bebas, yaitu dalam kaitan ini memiliki dua variable bebas (atau lebih). Pada bagian ini ditampilkan tabel koefesien regresi berganda yang diolah dari data interval atau rasio gabungan dari ketiga variabel, yaitu sebagai berikut:

Tabel 17

Hasil Uji Regresi Berganda Variabel $X_{1}$ Variabel $\mathrm{X}_{2}$ Terhadap Variabel $\mathrm{Y}$

\begin{tabular}{|c|c|c|c|c|c|}
\hline \multicolumn{6}{|c|}{ Coefficients $^{\mathrm{a}}$} \\
\hline \multirow[t]{2}{*}{ Model } & \multicolumn{2}{|c|}{$\begin{array}{l}\text { Unstandardized } \\
\text { Coefficients }\end{array}$} & \multirow{2}{*}{$\begin{array}{c}\begin{array}{c}\text { Standardize } \\
d \\
\text { Coefficients }\end{array} \\
\text { Beta }\end{array}$} & \multirow[t]{2}{*}{$t$} & \multirow[t]{2}{*}{ Sig. } \\
\hline & B & Std. Error & & & \\
\hline (Constant) & 52.317 & 8.586 & & 6.093 & .000 \\
\hline Tata Kelola Pemilih & .260 & .110 & 268 & 2.376 & .020 \\
\hline $\begin{array}{l}\text { Penyiapan logistik } \\
\text { Pemilu }\end{array}$ & .093 & .100 & .105 & .928 & .356 \\
\hline
\end{tabular}

Berdasarkan perhitungan yang telah ditemukan melalui analisis data pada tabel $17 \mathrm{di}$ atas, diketahui nilai konstanta a dan koefesien b yang ditunjukkan pada perhitungan regresi linier berganda di atas dapat dihitung ke dalam rumus sebagai berikut:

$$
\hat{\mathrm{Y}}=52.317+0.260 .(\mathrm{X} 1)+0.093 .(\mathrm{X} 2)
$$

Diketahui nilai konstanta 52.317. Ini berarti pada Tata Kelola Pemilih dan Penyiapan Logistik Pemilu lebih meningkat maka Efektivitas Pemilu Gubernur dan Wakil Gubernur Banten Tahun 2017 (Y), pun akan bertambah. Koefesien regresi untuk Tata Kelola Pemilih (0.260) lebih besar daripada koefesien regresi untuk Penyiapan Logistik Pemilu (0.093). Jadi bila Tata Kelola Pemilih dan Penyiapan Logistik Pemilu lebih meningkat, maka Efektivitas Pemilu Gubernur dan Wakil Gubernur Banten Tahun 2017 menjadi :

$$
\begin{aligned}
\hat{Y} & =52.317+0.260 \cdot(1)+0.093 .(1) \\
& =52.317+0.260+0.093 \\
& =52.670
\end{aligned}
$$

Hal tersebut, memberikan gambaran bahwa arah hubungan antara Tata Kelola Pemilih dan Penyiapan Logistik Pemilu ternyata searah, dimana setiap kenaikan satu satuan pada variable bebas (Tata Kelola Pemilih dan Penyiapan Logistik Pemilu) akan menyebabkan kenaikan terhadap variable terikat (Efektivitas Pemilu Gubernur dan Wakil Gubernur Banten 2017) sebesar 52.670. Artinya bila Tata Kelola Pemilih dan Penyiapan Logistik Pemilu dapat dioptimalkan/ditingkatkan lebih baik, maka Efektivitas Pemilu Gubernur dan Wakil Gubernur Banten Tahun 2017 di KPU Kota Tangerang lebih bertambah meningkat.

\section{Pembahasan Hasil Penelitian}

Berdasarkan hasil penelitian dan analisis data Tata Kelolah Pemilih $\left(\mathrm{X}_{1}\right)$ dan Penyiapan Logistik Pemilu $\left(\mathrm{X}_{2}\right)$ Terhadap Efektivitas Pemilu Gubernur dan Wakil Gubernur Banten Tahun 2017 (Y), di KPU Kota Tangerang melalui tahapan uji hipotesis yang telah diuraikan di atas, maka pembahasan sebagai berikut:

Pengujian hipotesis kesatu terdapat pengaruh positif dan signifikan antara Tata Kelolah Pemilih $\left(\mathrm{X}_{1}\right)$ Terhadap Efektivitas Pemilu Gubernur dan Wakil Gubernur Banten Tahun 2017 (Y), (Y) sebesar $\mathrm{r}=0.315$. Koefesien korelasi ini signifikan dan memiliki tingkat hubungan rendah berada pada interval nilai 0.200-0.399. Sedangkan hasil uji thitung yang dikonsultasikan $\mathrm{t}_{\text {tabel }}$ hasilnya ternyata variable $\mathrm{X}_{1}$ (Tata Kelolah Pemilih) terhadap variable Y (Efektivitas Pemilu Gubernur dan Wakil Gubernur Banten 2017) hasil uji hipotesis ke-1 Ho ditolak dan Ha diterima karena $t_{\text {hitung }}$ (3.114) $>\mathrm{t}_{\text {tabel }}$ (1.980). Variabel $\mathrm{X}_{2}$ (Penyiapan Logistik Pemilu) terhadap Variabel Y (Efektivitas Pemilu Gubernur dan Wakil Gubernur Banten 2017).

Hasil perhitungan SPSS pada tabel 10, menunjukkan nilai $\mathrm{t}_{\text {hitung }}$ untuk Tata Kelolah Pemilih (X1) diperoleh nilai sebesar 3.114. Adapun harga $\mathrm{t}_{\text {tabel }}$ untuk dk $(90-2=88)$ dalam nilai-nilai distribusi $t$ untuk uji dua pihak taraf signifikan 0.05 menunjukkan skor nilai 1.980. 
Hal ini membuktikan bahwa $\mathrm{t}_{\text {hitung }}(3.114)>$ $\mathrm{t}_{\text {tabel }}$ (1.980). Dengan demikian Ho ditolak dan Ha diterima. Dapat ditarik kesimpulan bahwa terdapat pengaruh yang signifikan antara Tata Kelolah Pemilih $\left(\mathrm{X}_{1}\right)$ Terhadap Efektivitas Pemilu Gubernur dan Wakil Gubernur Banten Tahun 2017 (Y), di KPU Kota Tangerang. Persamaan regresi yang digunakan untuk melakukan prediksi (ramalan) dalam variable dependen akan terjadi bila dalam variable indevenden ditetapkan. Jadi bila Tata Kelolah Pemilih $\left(\mathrm{X}_{1}\right)$ di KPU meningkat/ ditingkatkan hingga mendapat nilai 1, maka Efektivitas Pemilu (Y) menjadi : $\hat{\mathrm{Y}}=55.769+0.306 .1=$ 56.075

Jadi diperkirakan Efektivitas Pemilu Gubernur dan Wakil Gubernur Banten Tahun 2017 (Y), akan meningkat sebesar 56.075. Dengan demikian, Efektivitas Pemilu Gubernur dan Wakil Gubernur Banten Tahun 2017 akan naik, bila Tata Kelolah Pemilih lebih meningkat. Hal ini membuktikan bahwa variable indevenden $\mathrm{X}_{1}$ (Tata Kelola Pemilih) searah terhadap naiknya turunnya variable dependent Y (Efektivitas Pemilu Gubernur dan Wakil Gubernur Banten Tahun 2017.

Pengujian hipotesis kedua terdapat pengaruh positif dan signifikan Penyiapan Logistik Pemilu $\left(\mathrm{X}_{2}\right)$ Terhadap Efektivitas Pemilu Gubernur dan Wakil Gubernur Banten Tahun 2017 (Y), sebesar 1.000. Koefesien korelasi ini signifikan dan memiliki tingkat hubungan sangat tinggi berada pada interval nilai 0.800 1.000. Dan hasil uji hipotesis ke-2 Ha diterima dan Ho ditolak karena $t_{\text {hitung }}(2.157)>\mathrm{t}_{\text {tabel }}(1.980)$. Selanjutnya untuk variable $\mathrm{X}_{1}$ (Tata Kelolah Pemilih) dan Variabel $\mathrm{X}_{2}$ (Penyiapan Logistik Pemilu) terhadap variable Y (Efektivitas Pemilu Gubernur dan Wakil Gubernur Banten Tahun 2017 (Y),). Nilai thitung untuk Penyiapan Logistik Pemilu (X2) diperoleh nilai sebesar 2.157. Adapun harga $\mathrm{t}_{\text {tabel }}$ untuk $\mathrm{dk}(90-2=88)$ dalam nilai-nilai distribusi t untuk uji dua pihak taraf signifikan 0.05 menunjukkan skor nilai 1.980. Hal ini membuktikan bahwa $t_{\text {hitung }}(2.157)>$ $t_{\text {tabel }}$ (1.980). Dengan demikian Ho ditolak dan Ha diterima. Dapat ditarik kesimpulan bahwa terdapat pengaruh yang signifikan antara Penyiapan Logistik Pemilu $\left(\mathrm{X}_{2}\right)$ Terhadap Efektivitas Pemilu Gubernur dan Wakil Gubernur Banten Tahun 2017 (Y), di KPU Kota Tangerang.

Persamaan regresi yang digunakan untuk melakukan prediksi (ramalan) dalam variable dependen akan terjadi bila dalam variable indevenden ditetapkan. Jadi bila Penyiapan Logistik Pemilu $\left(\mathrm{X}_{2}\right)$ di KPU meningkat/ ditingkatkan hingga mendapat nilai 1 , maka Efektivitas Pemilu Gubernur dan Wakil Gubernur Banten Tahun 2017 (Y), menjadi :

$\hat{\mathrm{Y}}=64.781+0.199 .1=64.980$

Jadi diperkirakan Efektivitas Pemilu Gubernur dan Wakil Gubernur Banten Tahun 2017 (Y), akan meningkat sebesar 64.980. Dengan demikian, Efektivitas Pemilu Gubernur dan Wakil Gubernur Banten Tahun 2017 (Y), akan naik, bila Penyiapan Logistik Pemilu lebih meningkat. Hal ini membuktikan bahwa variable indevenden $\mathrm{X}_{2}$ (Penyiapan Logistik Pemilu) searah terhadap naiknya turunnya variable dependent Y (Efektivitas Pemilu Gubernur dan Wakil Gubernur Banten 2017).

Pengujian hipotesis ketiga pada uji statistic korelasi berganda (R) menujukan terdapat pengaruh positif dan signifikan antara Tata Kelolah Pemilih $\left(\mathrm{X}_{1}\right)$ dan Penyiapan Logistik Pemilu $\left(\mathrm{X}_{2}\right)$ Terhadap Efektivitas Pemilu Gubernur dan Wakil Gubernur Banten Tahun 2017 (Y), sebesar 0.329. Hal ini menujukan adanya pengaruh lemah antara Tata Kelolah Pemilih (X1) dan Penyiapan Logistik Pemilu (X2) secara bersama-sama terhadap Efektivitas Pemilu Gubernur dan Wakil Gubernur Banten Tahun 2017 (Y). Dan uji hipotesis ke-3 Ha diterima dan Ho ditolak setelah dikonsultasikan dengan $\mathrm{F}_{\text {tabel }}$ ternyata $\mathrm{F}_{\text {hitung }}(5.272)>\mathrm{F}_{\text {tabel }}$ (1.39), maka secara bersama-sama $\mathrm{X}_{1}$ (Tata Kelola Pemilih) dan $\mathrm{X}_{2}$ (Penyiapan Logistik Pemilu) berpengaruh terhadap Y (Efektivitas Pemilu Gubernur dan Wakil Gubernur Banten 2017). 
Sedangkan pada perhitungan regresi linier berganda nilai konstanta a dan koefesien b yang terdapat dalam rumus sebagai berikut:

$$
\hat{\mathrm{Y}}=52.317+0.260 .(\mathrm{X} 1)+0.093 .(\mathrm{X} 2)
$$

Diketahui nilai konstanta 52.317. Ini berarti pada Tata Kelola Pemilih dan Penyiapan Logistik Pemilu lebih meningkat maka Efektivitas Pemilu Gubernur dan Wakil Gubernur Banten Tahun 2017 (Y), pun akan bertambah. koefesien regresi untuk Tata Kelola Pemilih (0.260) lebih besar daripada koefesien regresi untuk Penyiapan Logistik Pemilu (0.093). Jadi bila Tata Kelola Pemilih dan Penyiapan Logistik Pemilu lebih meningkat, maka Efektivitas Pemilu Gubernur dan Wakil Gubernur Banten Tahun 2017 menjadi :

$$
\begin{aligned}
\hat{Y} & =52.317+0.260 .(1)+0.093 \cdot(1) \\
& =52.317+0.260+0.093 \\
& =52.670
\end{aligned}
$$

Hal tersebut, memberikan gambaran bahwa arah hubungan antara Tata Kelola Pemilih dan Penyiapan Logistik Pemilu ternyata searah, dimana setiap kenaikan satu satuan pada variable bebas (Tata Kelola Pemilih dan Penyiapan Logistik Pemilu) akan menyebabkan kenaikan terhadap variable terikat (Efektivitas Pemilu Gubernur dan Wakil Gubernur Banten Tahun 2017 (Y), sebesar 52.670. Artinya bila Tata Kelola Pemilih dan Penyiapan Logistik Pemilu dapat dioptimalkan/ditingkatkan lebih baik, maka Efektivitas Pemilu Gubernur dan Wakil Gubernur Banten Tahun 2017 di KPU Kota Tangerang lebih bertambah meningkat.

\section{KESIMPULAN DAN SARAN \\ Kesimpulan}

Berdasarkan hasil analisis uji statistic dan pembahasan tentang Tata Kelola Pemilih dan Penyiapan Logistik Pemilu Terhadap Efektivitas Pemilu Gubernur dan Wakil Gubernur Banten Tahun 2017 di Kota Tangerang dapat disimpulkan sebagai berikut:

1. Terdapat pengaruh positif dan signifikan tata kelola pemilih terhadap efektivitas Pemilu Gubernur dan Wakil Gubernur
Banten 2017 sebesar 0.315. Koefesien korelasi ini signifikan dan memiliki tingkat hubungan rendah berada pada interval nilai 0.200-0.399.

Jadi diperkirakan efektivitas Pemilu Gubernur dan Wakil Gubernur Banten 2017 akan meningkat sebesar 56.075. Dengan demikian, efektivitas Pemilu Gubernur dan Wakil Gubernur Banten 2017 akan naik, bila Tata Kelola Pemilih lebih meningkat. Hal ini membuktikan bahwa variable indevenden tata Kelola Pemilih searah terhadap naiknya turunnya variable dependent efektivitas Pemilu Gubernur dan Wakil Gubernur Banten Tahun 2017 (Y).

2. Terdapat pengaruh positif dan signifikan penyiapan logistik pemilu terhadap efektivitas Pemilu Gubernur dan Wakil Gubernur Banten 2017 sebesar 1.000. Koefesien korelasi ini signifikan dan memiliki tingkat hubungan sangat tinggi berada padainterval nilai 0.800-1.000. Persamaan regresi yang digunakan untuk melakukan prediksi (ramalan) dalam variable dependen akan terjadi bila dalam variable indevenden ditetapkan. Jadi bila Penyiapan Logistik Pemilu di KPU meningkat/ ditingkatkan hingga mendapat nilai 1, maka Efektivitas Pemilu Gubernur dan Wakil Gubernur Banten menjadi : $\hat{Y}=64.781+0.199 .1=$ 64.980 .

3. Terdapat pengaruh positif dan signifikan antara Tata Kelolah Pemilih dan Penyiapan Logistik Pemilu Terhadap Efektivitas Pemilu Gubernur dan Wakil Gubernur Banten 2017 sebesar 0.329. Hal ini menunjukkan adanya pengaruh lemah antara Tata Kelolah Pemilih dan Penyiapan Logistik Pemilu secara bersama-sama terhadap Efektivitas Pemilu Gubernur dan Wakil Gubernur Banten Tahun 2017. Hubungan antara Tata Kelola Pemilih dan Penyiapan Logistik Pemilu ternyata searah, dimana setiap kenaikan satu satuan pada variable bebas (Tata Kelola Pemilih 
dan Penyiapan Logistik Pemilu) akan menyebabkan kenaikan terhadap variable terikat (Efektivitas Pemilu Gubernur dan Wakil Gubernur Banten Tahun 2017 (Y), ) sebesar 52.670. Artinya bila Tata Kelola Pemilih dan Penyiapan Logistik Pemilu dapat dioptimalkan/ditingkatkan lebih baik, maka Efektivitas Pemilu Gubernur dan Wakil Gubernur Banten Tahun 2017 di KPU Kota Tangerang lebih bertambah meningkat.

\section{Saran}

Berdasarkan temuan-temuan yang telah didapat pada penelitian ini, maka saran yang dapat dikemukakan adalah:

1. Efektivitas Pemilu Gubernur dan Wakil Gubernur Banten masih perlu ditingkatkan dengan cara memaksimalkan pendataan dalam tata kelola pemilih dan penyiapan logistik pemilu di KPU Kota Tangerang, agar tercipta pemilu yang berkualitas dan menghasilkan para pemimpin atau wakil rakyat yang berkualitas juga sehingga apa yang mereka perbuat demi kepentingan rakyat bukan demi tujuan individu atau golongan.

2. KPU Kota Tangerang harus berupaya meningkatkan tata kelola pemilih dengan melakukan pembinaan dan pengawasan serta imbalan yang intensif kepada PPK (Panitia Pemilihan Kecamatan) dan PPS (Panitia Pemungutan Suara). Dan memaksimalkan penyiapan logistik pemilu dengan melakukan pendistribusian logistik pemilu sesuai dengan jadwal pengiriman agar tidak terjadi keterlambatan pengiriman logistik pemilu sehingga menggangu PPK dalam pengepakan logistik tersebut. KPU, Pemerintah dan Partai Politik peserta Pemilu harus berupaya meningkatkan peran serta masyarakat dalam pengelolan daftar pemilih, agar tidak terjadi kesalahan dalam tata kelola pemilih, seperti nama dobel, tidak terdaftar dalam DPT, dan yang sudah meninggal masih terdaftar di dalam DPT.

3. Penyiapan logistik pemilu perlu ditingkatkan, karena termasuk unsur terpenting dalam Pemilu, misalnya dengan adanya tanggung jawab yang jelas pada logistik pemilu kepada penyelenggara Pemilu sampai ke tingkat PPS. Artinya PPK dan PPS juga diberikan kepercayaan atau tanggungjawab dalam penyiapan logistik pemilu bukan hanya menunggu logistik pemilu dari KPU saja.

\section{DAFTAR PUSTAKA}

Akhmadi, Nuning. 2004. Tata Kelola Pemerintah dan Penanggulangan Kemiskinan : Bukti Awal Desentralisasi di Indonesia. Jogjakarta Anatan, Lina dan Ellitan, Lena. 2007. Manajemen Sumber Daya Manusia Dalam Bisnis Modern. Bandung: Alfabeta.

Anderson, Kirsten L., Daniel N. Deli Dan Stuart L. Gillan. 2003. Dewan Direksi,Komite Audit, dan Isi Informasi Laba.

Arikunto Suharsimi. 2006. Prosedur Penelitian: Suatu Pendekatan Praktek. Jakarta: Rineka Cipta.

Ballou H Ronald. 2002. Business Logistik Management. Text Book.

Bowersox J Donald. 2006. Manajemen Logistik : Integrasi Sistem-Sistem Management Distribusi Fisik dan Materi Management. Terjemahan A. Hasymi Ali. Jakarta: Bumi Aksara.

Budiarjo Miriam. 2013. Dasar-dasar Ilmu Politik. Edisi Revisi. Cetakan ke Sembilan. Jakarta: PT. Gramedia Pustaka Utama

Cardoso. Faustino. Gomes. 2003. Manajemen Sumber Daya Manusia. Jogjakarta: PT. Andi

Christop Scuk dan Wanata H Sugeng. 2002. Demokrasi di Indonesia: Teori dan Praktek. Jogjakarta: Graha Ilmu.

Depaetemen Pendidikan Nasional. 2005. Kamus Besar Bahasa Indonesia. Edisi ketiga. Jakarta: Balai Pustaka 
Dwiantara Lukas dan Rumsari H.S. 2004, Managemen logistik Pedoman Praktis bagi Sekretaris dan Sttaf Administrasi, Grasindo.

Hadi Sutrisno. 2009. Metodologi Research 1. Jogjakarta: Andi Publisher

Hasibuan, Malayu S.P. 2005. Manjemen Sumber Daya Manusia Edisi Revisi. Jakarta: Bumi Aksara.

Heryanto Gun-gun. 2011. Dinamika Komunikasi Politik Indonesia. Jakarta: Lasswell Visitama

Irianto, Jusuf. 2001. Tema-Tema Pokok Sumber Daya Manusia. Jakarta: Insan Cendikia.

Jones Gareth. 2010. Organizational Theory, Design, and Change

Kementerian Pendayagunaan Aparatur Negara. 2005. Clean Government dan Good Government Untuk meningkatkan Kinerja Birokrasi Dan Pelayanan Publik. Jakarta

Nazir Mohammad. 2003. Metode Penelitian. Jakarta: Ghalia Indonesia

Pedoman Pelaksana Pengadaan Barang/ Jasa Pemerintah. 2007. Jakarta: Visimedia

Prabu, Anwar . 2005. Manajemen Sumber Daya Manusia Perusahaan. Bandung: Remaja Rosdakarya.

Rahardjo Adisasmita, 2011. Pengelolaan Pendapatan dan Anggaran Daerah. Yang Menerbitkan Graha Ilmu : Yogyakarta.

Robbins, Stephen P, 2003. Perilaku Organisasi, Jakarta : Indeks.

Santoso Pandji. 2008. Administrasi Publik Teori dan Aplikasi Good Governance. Bandung: Refika Aditama.

Sastradipoera, Komarudin. 2001. Asas-Asas Manajemen Perkantoran. Bandung: Kappa Sigma.

Siagian M Yolanda. 2005. Aplikasi Supply Chain Management. Grasindo.

Siagian P Sondang. 2003. Teori Pengembangan Organisai. Jakarta: Bumi Aksara

Simamora, Henry. 2004. Manjemen Sumber Daya Manusia. Yogyakarta: STIE YKPN.

Steers, M Richard. 2005. Efektivitas Organisasi. Jakarta: Erlangga
Sugiono. 2003. Metode Penelitian Administrasi: dilengkapi dengan Metode $R$ \& B. Bandung: Alfabeta

Sugiono. 2007. Metode Penelitian Kualitatif: dilengkapi dengan Metode $R$ \& $B$. Bandung: Alfabeta

Syafiie K Inu. 2006. Ilmu Administrasi Publik. Jakarta. Rineka Cipta

Turnbull Shann. (1997) Corporate governance pioneer who initiated in 1971 the first education course in the world to provide company directors with a professional qualification in 1975.

Wahana Komputer. 2011. Mudah Belajar Statisti dengan SPSS 20. Jogjakarta: Andi Offset

Undang-undang Dasar 1945

Undang-Undang No. 10 Tahun 2016 Tentang perubahan kedua atas Undang-undang No 1 Tahun 2015 tentang penetapan peraturan pemerintah pengganti undang-undang no 1 tahun 2014 tentang Pemilihan Gubernur, Bupati dan Walikota menjadi undangundang

Peraturan Komisi Pemilihan Umum PKPU tentang Pemilihan Gubernur, Bupati dan Walikota. KPU Provinsi Banten

Peraturan Komisi Pemilihan Umum No. 09 Tahun 2013 Tentang Penyusunan Daftar Pemilih Untuk Pemilihan Umum

Peraturan Komisi Pemilihan Umum No. 16 Tahun 2013 Tentang Norma, Standar kebutuhan Pengadaan dan Pendistribusian Perlengkapan Penyelenggaraan Pemilihan Umum Peraturan Komisi Pemilihan Umum No. 21 Tahun 2013 Tentang Perubahan keenam Atas Peraturan Komisi Pemilihan Umum No.07 Tahun 2012 Tentang Tahapan, Jadual dan Penyelenggaraan Pemilihan Umum

Majalah Suara KPU. Edisi 1 Oktober 2014 